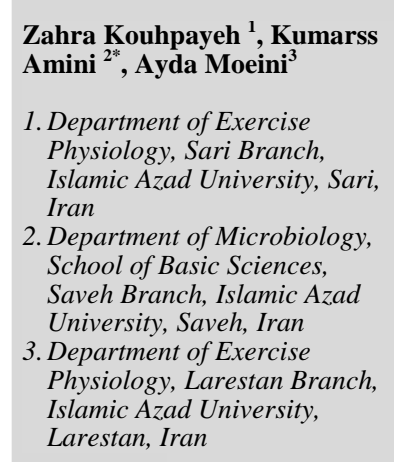

\section{Detection Mycoplasma hominis and genitalium in Urine Samples from Athletes and Non-Athletes by Multiplex- PCR Method}

Received: 31 Jan. 2017 ; Accepted: 18 Aug. 2017

\section{Abstract}

Backgrounds and Objectives: Mycoplasmas are distinguished phenotypically from other bacteria by their minute size and total lack of a cell wall and are involved in urogenital infections in both male and females. The aim of this study was to evaluate the presence of Mycoplasma genus and Mycoplasma homonis and genitalium in urine samples of athletes and non-athletes.

Methods: In this study, urine samples were taken from 50 athlete and non-athlete males and were transported to laboratory. After DNA extraction, PCR was performed using specific primers to identify Mycoplasma genus and species hominis and genitalium.

Results: Among 100 samples, 5 were positive for Mycoplasma genus which all the 5 isolate belonged to non-athlete persons. In 5 positive samples, 3 belonged to Mycoplasma hominis and 2 belonged to Mycoplasma genitalium.

Conclusions: This study showed the presence of Mycoplasma in athletes were less than non-athletes. In addition PCR was a sensitive and precise method to identify Mycoplasma genus and species.

Keywords: Mycoplasma genitalium, Mycoplasma hominis, Urogenital infection 


\section{شناسايى مايكويلاسما هومينيس و مايكويلاسما جنيتاليوم در نمونه ادرار افراد ورزشكار و غير ورزشكار به روش Multiplex- PCR}

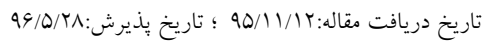

\section{حك)}

زمينه و هدف: مايكويهلاسماها بهواسطه داشتن اندازه كوجّى و فقدان ديواره سلولى از ساير باكترىها متمايز مسى گردنـد و در بروز عفونت هاى ادرارى-تناسلى در مردان وزنان نقش دارند. هدف از اين مطالعه بررسى حضور جنس مايكويلاسـما و كونهاي مايكوبِاسما هومينيس و جنيتاليوم در ادرار افراد ورزشكار حرفهاى و غير ورزشكار مىباشد. روش بررسى: در اين ئزوش تجربى از •ه مرد ورزشكار حرفهاى و •ه مرد غير ورزشكار نمونه ادرارى اخذ گرديد و به آزمايشگاه انتقال داده شد. يُ از استخراج DNA، و اكنش PCR با استفاده از يرايمرهاى اختصاصى جهت شناسايى جنس

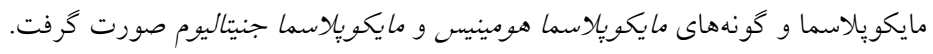
يافته ها: در اين ثيزوهش از · ا نمونه اخذشده ه نمونه ازلحاظ جنس مايكويلاسما مثبت بودند كه هر ه نمونه مربـوط بـه افراد غير ورزشكار بود. از ه نمونه مثبت جنس، ب نمونه متعلق به كونه مايكوبِاسما هومينيس و ب نمونه متعلـق بـه كونسه ما يكوبِاسما جنيتاليوم بودند. نتيجه گيرى: در اين ثزوهش نشان داده شد ميزان آلودخى به مايكويلاسماها در افرادى كه داراى فعاليـت ورزشسى حرفـهاى هستند كمتر از ساير افراد مىباشد. بهعـلاوه روش PCR روشسى حسـاس و دقيـق جهـت شناسـايى جــس و كونسههـاى

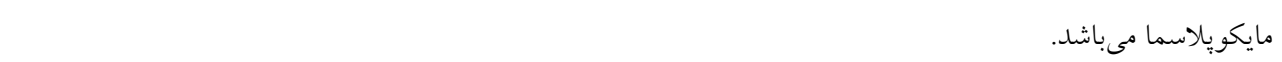
كلمات كليدى: مايكوبِلاسما جنيتاليوم، مايكوبِاسما هومينيس، عفونت ادرارى-تناسلى

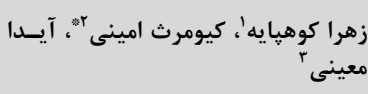

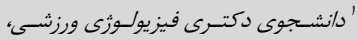

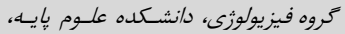

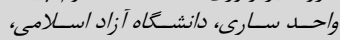

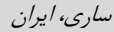

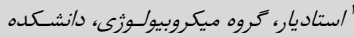

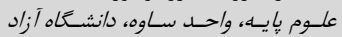

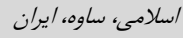

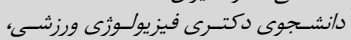

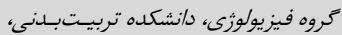

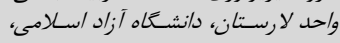

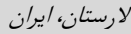


تناسلى و متعاقباً مشـكلات بعـدى از قبيـل عفونـتهــاى ادرارى و مشكلات نابارورى، بررسى حضور اين باكترىها در افراد ورزشكار

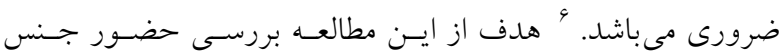

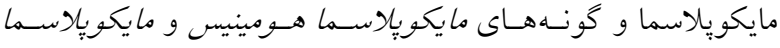
جنيتـاليوم در نمونسههـاى ادرار افـراد ورزشـكار حرفـهاى و غيـر ورزشكار با روش PCR مى باشد.

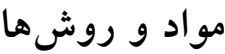

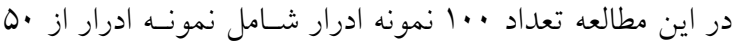

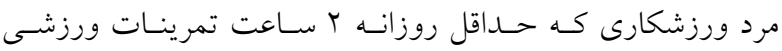
داشتهاند و •ها مرد غير ورزشـكار كـه در طـول هفتـه كمتــ از نسيم ساعت حركات ورزشى داشتهاند بررسى شــند. همخـى ايسن افـراد متأهل در طول ماه اغلب حدود Y بار رابطه جنسى برقرار مىكردنـــ

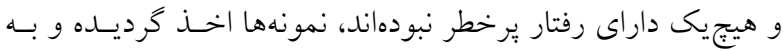

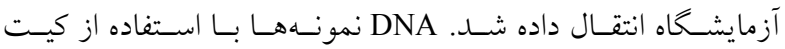
استخراج DNA شركت كيازن، اسـتخراج گرديـــ. جهـت شناسـايى جــنس مايكو يلاســما از زن 16SrRNA مايكويلاسـما اسـتفاده شـــ. نمونههاى مثبت جـــس مايكويلاسـما جهـت شناسـايى كونـهـهـاى ما يكويلاسـما جنيتـاليوم و ما يكويلاسـما هـومينيس بـا اسـتفاده از

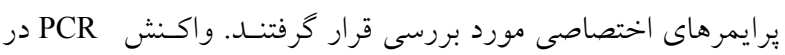

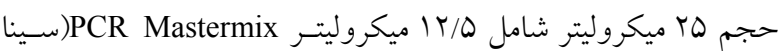
زن)، إميكروليتر از هر يرايمر و بميكروليتر از DNA الحـو انجـام كرفت. شرايط سيكل حرارتى براى PCR بدين شرح بود: واسرشت

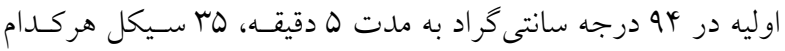
شامل: واسرشت در عq درجه سانتى گراد به مــدت ادقيقهـ، اتصـال

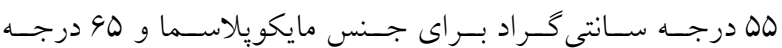
سانتى گراد براى گونه هاى مايكويلاســما جنيتـاليوم و هـومينيس بــهـ مدت ا دقيقه، مرحله بسط در VY درجه سانتى گراد به مدت ا دقيقه و نيـز بسط نهـايى در VT درجسه سـانتى گـراد بـه مـــات V دقيقـه.

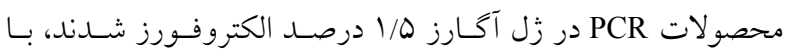
اتيديوم برومايد رنخ آميـزى شــندل و تحـت نـور UV مشـاهده و

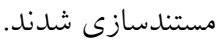

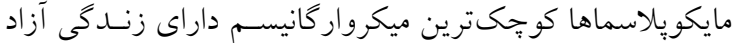
و فلور نرمال دهان، دستخاه تنفسى و ادرارى - تناسـلى مسىباشـــد. اين باكترى اندازه بسيار كو جك دارد و فاقد ديواره سلولى اسـت و و

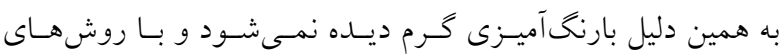

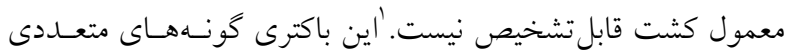
دارد و در انسان بيمارىهاى مختلف ايجاد مى كند. مهمتـرين كونـه هاى آن عبارتند از: ما يكويِلاسما ينومونيسه، مايكويلاسـما جنيتـاليوم، ما يكويلاسما هومينيس، ما يكويلاسما فرمنتاس، مايكويِلاسما /ورالهه،

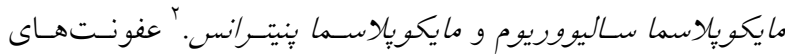
ادرارى-تناسلى نقش مهمى در ايجاد نابارورى در مردان وزنان دارد

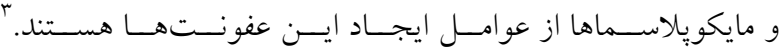
ما يكوِِلاسما هومينيس در ايجـاد اورتريست غير گنوكـوكى، وازينـوز باكتريايى، تب بعد از زايمان و بندرت باكتريمى، بريتونيت، آرتريت

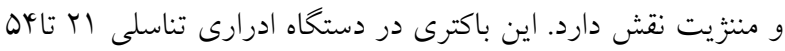
درصد زنان و ץ تا سا درصد مردان ديده مى شـود و انتقـال جنسى دارد و از عوامل نابارورى در مردان وزنان مىباشد. ايسن بـاكترى در مجراى تناسلى و منى مردان بارور و غير بـارور وجـود دارد و روى

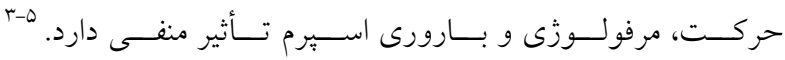
ما يكويِاسما جنيتاليوم عامل مسبب اورتريت غير كنوكوكى مىباشـد.

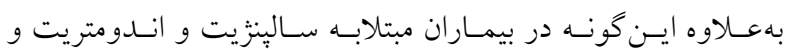

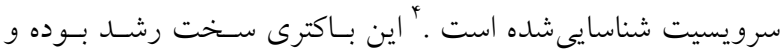
نيازهاى غذايى بييجيدهاى دارد. بهعلاوه به علت فرورفتن كلنى ها در

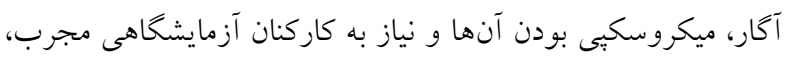
كشت و جداسازى ايسن بـاكترى بـهــور روتسين در آزمايشـاههـا صورت نمى گيرد. به همين دليل امروزه از روش هاى سريعتر مانتسـد در شناسايى آن بهره بـرده مسىشـود. ' ورزشـكاران بـه دليـل تمرينات ورزشى منظم انتظار مى رود ازلحساظ فاكتورهـاى سـلامت مانند فشارخون، وزن بدن، تحمل يه كلوكز و مقاومت به عفونتهـا در شرايط بهترى نسبت به ساير افراد قرار داشته باشند اما كاهى بـــ دليل استرس و نداشتن اسـتراحت كـافى، ضـعف ايمنسى و متعاقبـاً حساسيت بيشتر به عفونتها اتفاق مى افتد. به دليل اهميت دو گونسه. مايكويلاسما هومينيس و جنيتالوم در ايجـاد عفونـتهــــ ادرارى- 
جدول ا: تو الى ثرايمرهاى مورداستفاده در اين تحقيق

\begin{tabular}{|c|c|c|c|}
\hline اندازه محصول (bp) & توالى برايمر & 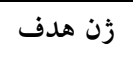 & برايمر \\
\hline \multirow[t]{2}{*}{194} & 5'-GGGAGCAAACAGGATTAGATACCCT-3' & $16 S r R N$ & GSO \\
\hline & 5-TGCACCATCTGTCACTCTGTTAACCTC - $3^{\prime}$ & A & MGSO \\
\hline \multirow[t]{2}{*}{ FrV } & 5'-TACATGCAAGTCGATCGGAAGTAGC-3' & $16 \operatorname{SrRN}$ & $45 \mathrm{~F}$ \\
\hline & 5'- AAACTCCAGCCATTGCCTGCTAG-3' & A & $447 \mathrm{R}$ \\
\hline \multirow[t]{2}{*}{ ref } & 5'-CAATGGCTAATGCCGGATACGC-3' & $16 \operatorname{SrRN}$ & RNAH1 \\
\hline & 5'-GGTACCGTCAGTCTGCAAT-3' & A & RNAH2 \\
\hline
\end{tabular}

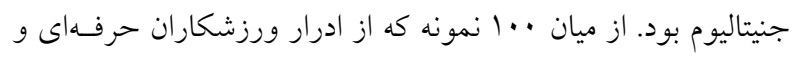

يافته ها

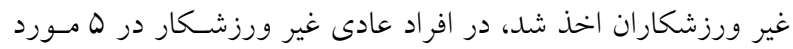

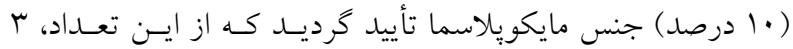

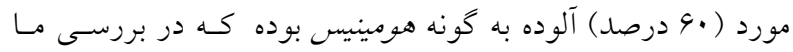

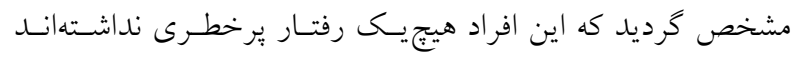

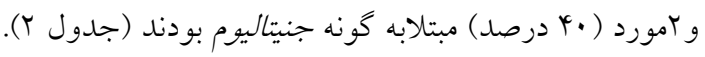

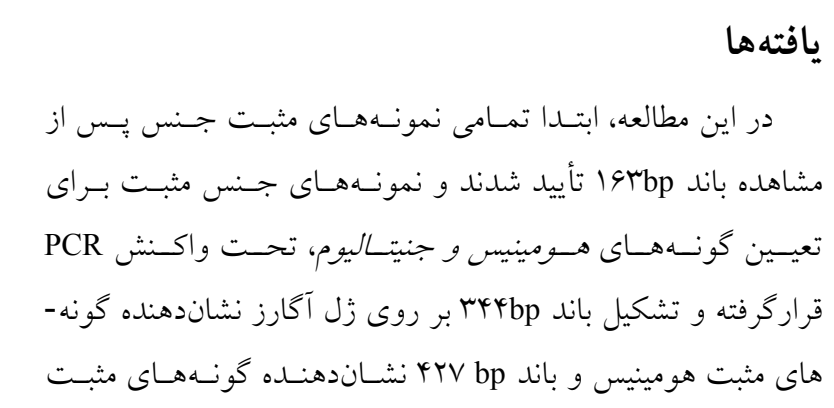

جدول r: توزيع فراوانى نمونههاى اخذشده بر اساس جنس و كونه موردمطالعه

\begin{tabular}{|c|c|c|c|c|c|c|}
\hline \multicolumn{2}{|c|}{ كونه مثبت جنيتاليوم } & \multicolumn{2}{|c|}{ كونه مثبت هومينيس } & \multicolumn{2}{|c|}{ جنس مثبت مايكويلاسما } & \\
\hline درصد & فراوانى & درصد & فراوانى & درصد & 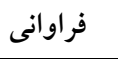 & \\
\hline . & · & . & . & . & . & ورزشكار حرفهاى \\
\hline r & r & 4 & $r$ & 1. & 0 & غير ورزشكار \\
\hline
\end{tabular}

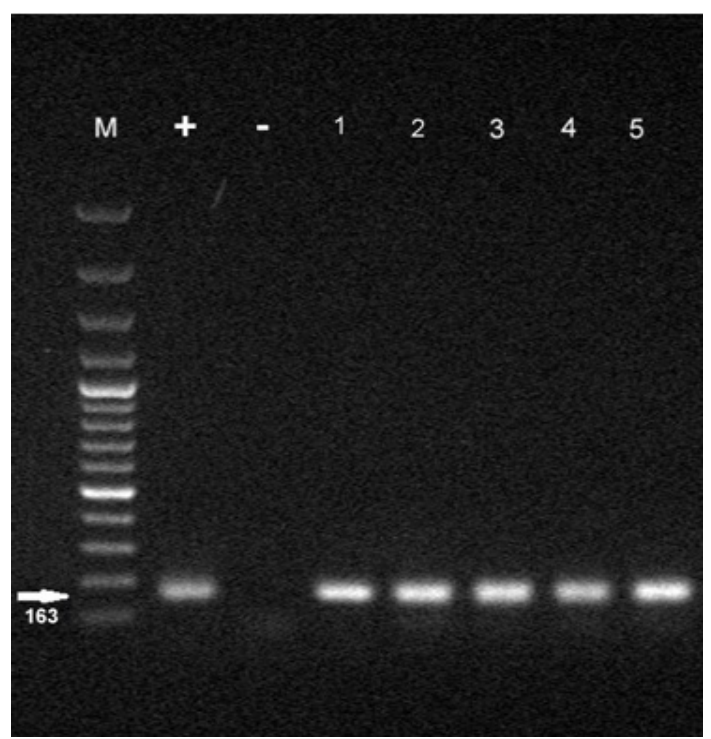

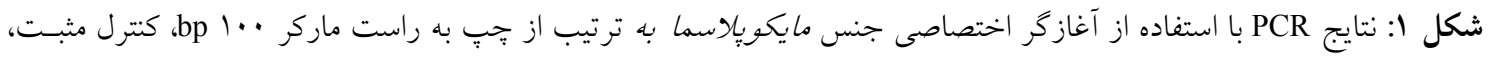

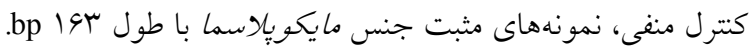




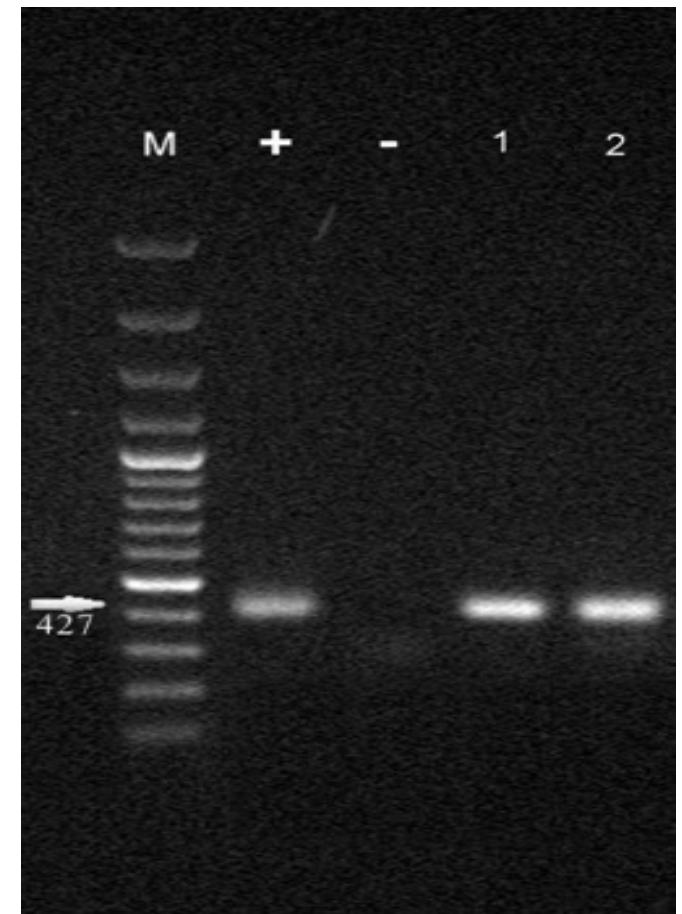

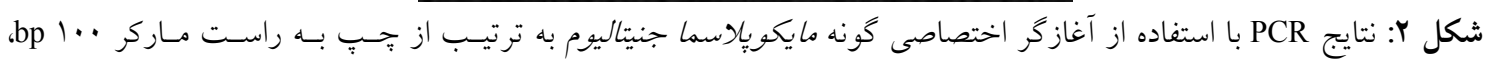

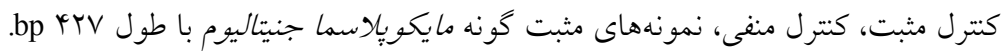

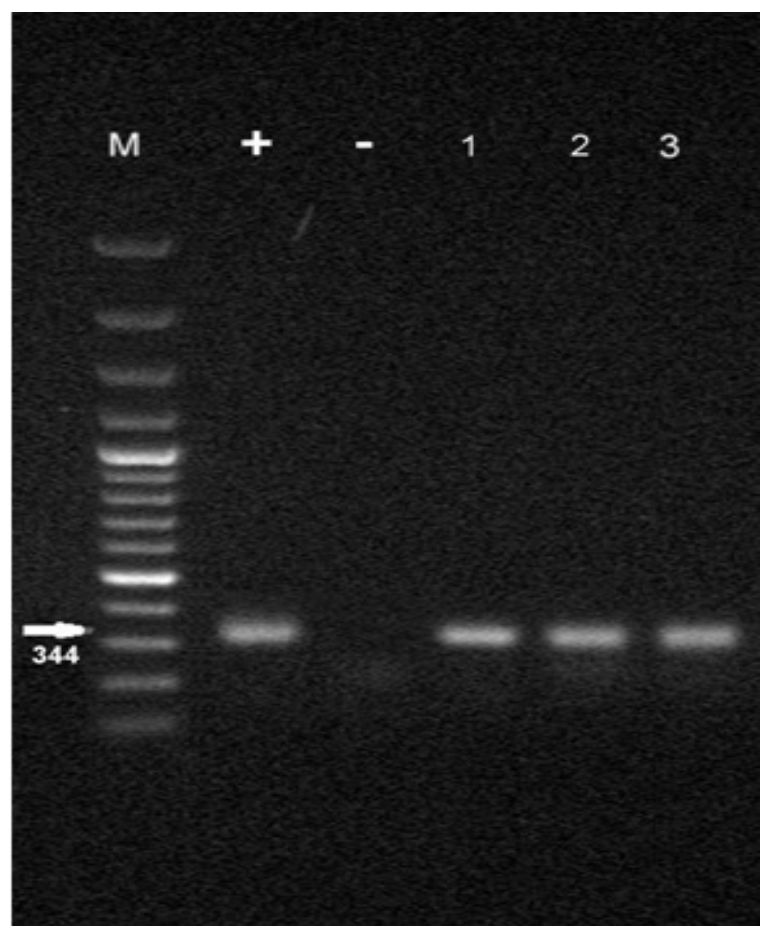

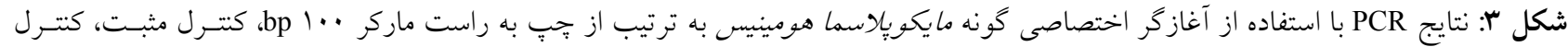

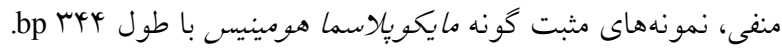


ازلحاظ وجود مايكويٌلاسماها با روش كشت و PCR بررسى شدند. در اين مطالعه IVY نمونه موردبررسى قرار كرفت كـه از ايـن ميـان

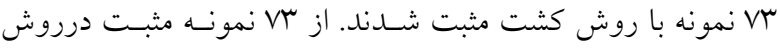

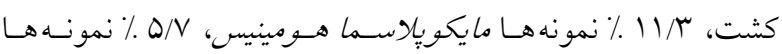
ما يكويلاسما جنيتاليوم بودند. ب.ا نمونه كشت منفى بـا روش PCR

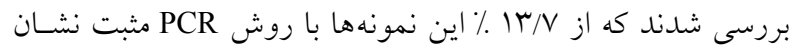

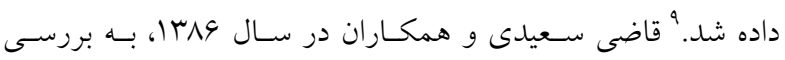

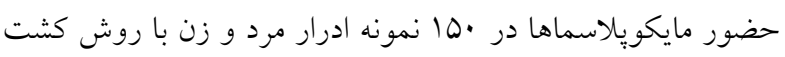

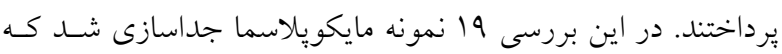

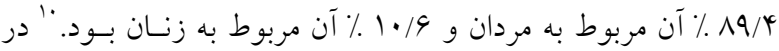

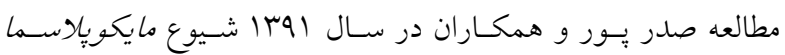

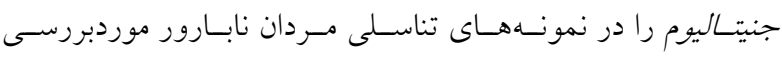

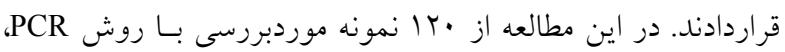

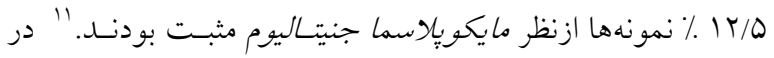
تحقيقى كـه توسط نجـار بيرايسه و صسميمى جهـت تشـخيص

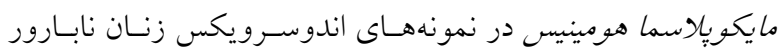

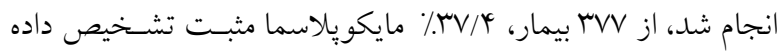

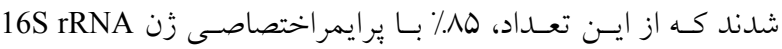

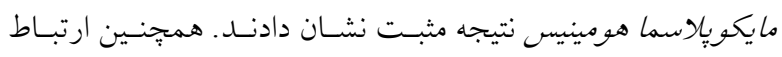

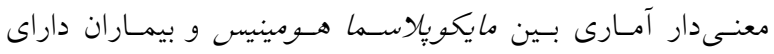

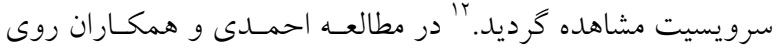
شناسـايى مايكوِِلاسـما هـومينيس در مـايع منسى مـردان نابـارور

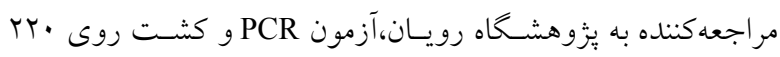

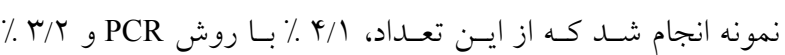
نمونهها با روش كشت آلودگى به ما يكوِيلاســا هـومينيس را نشـان

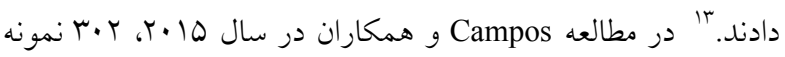

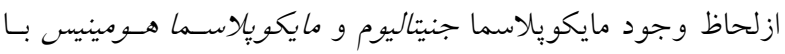

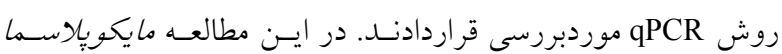

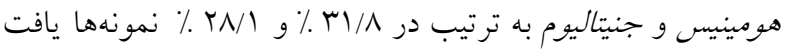
شد." در مطالعه Ikonomids و همكاران در سال 19 •.r، ץ.r نمونه

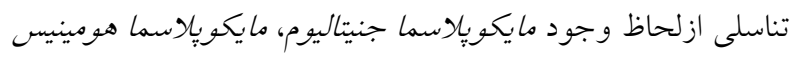

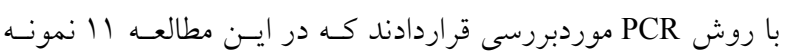

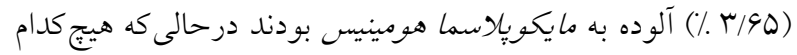

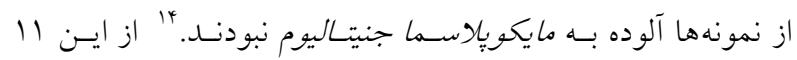

مايكويّلاسماها ازجمله اركانيسمهاى كمنسال دستّاه ادرارى-

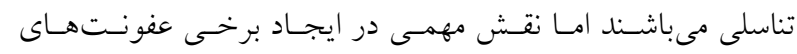

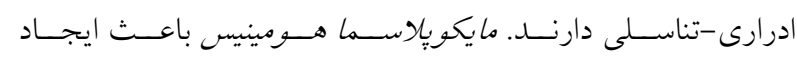

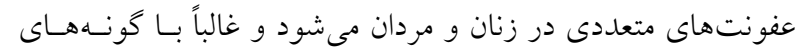

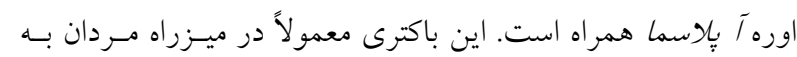

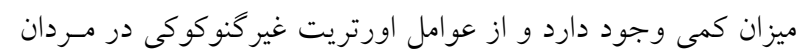

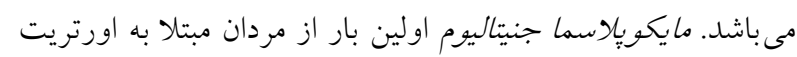

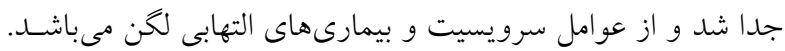
اين گونه كمتر به عنوان كمنسال دستخاه ادرارى - تناسـلى شـناخته شده است و معمولاً در موارد عفونت بالينى ديله مى شود. اين كونسه

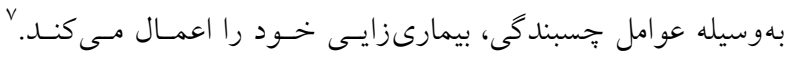

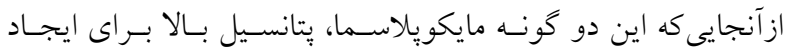

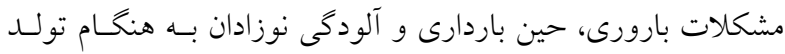

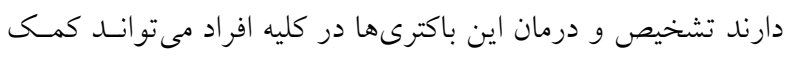

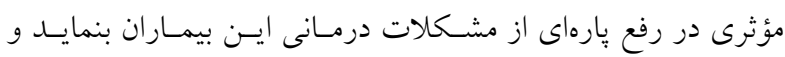

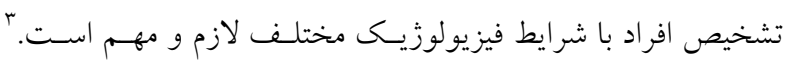
ازاينرو در مطالعه حاضر به بررسى حضور اين دو گونسه باكتريـايى

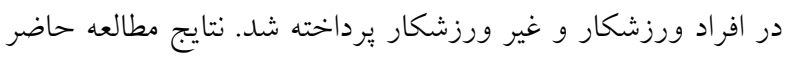

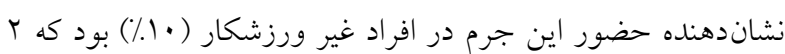

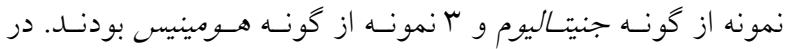

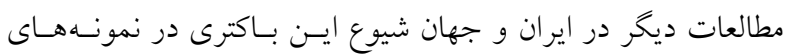
ادرارى-تناسلى با روشهاى كشت و PCR موردبررسى قرار كرفت.

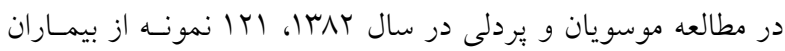

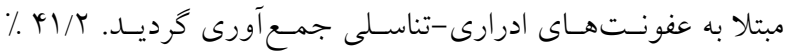
نمونهها ازلحاظ حضور مايكويلاسما هومينيس با روش كثت مثبت

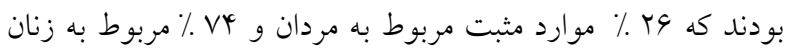

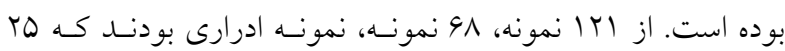

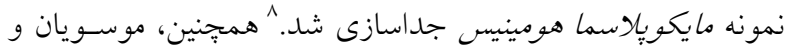
همكاران در سال •وس 1، حضور مايكويلاسما در نمونهاى ادرارى-

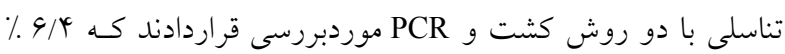

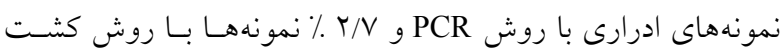
ازلحاظ وجود ما يكوِِلاسما هومينيس شناسايى شـدند.' در مطالعـه وطنى و همكاران در سال هی؟با، بيماران مبتلابه وازينـوز باكتريـايى 
آلودگى به مايكويلاسماها در نمونسهــاى تناسـلى مـردان نابـارور و بارور با روش PCR بررسى شد. در اين يُزوهش ميزان آلـودكى بـهـ

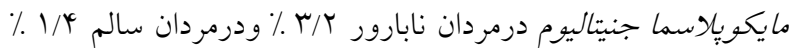

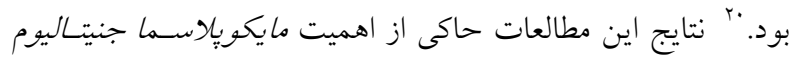

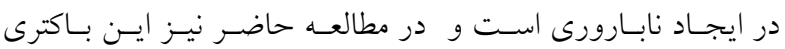
شناسايى شد و تعيين نقش دقيق آن در بيمارىهاى ادرارى-تناسلى دائى

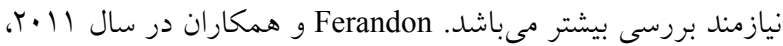
به مقايسه دو روش كشت و qPCR جهـت تشـخيص ما يكويلاسـما هومينيس در بما نمونه ادرارى تناسلى برداختند. در ايـن ي-رؤهش

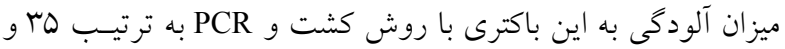

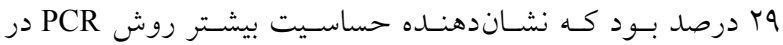

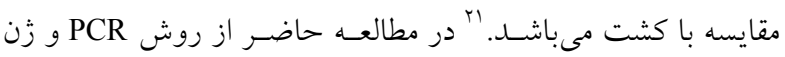

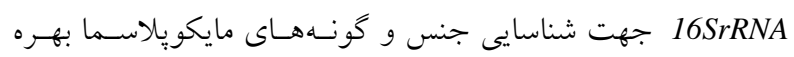
برده شد. روش PCR، علاوه بر سرعت، مشـكلات شناسـايى ايسن

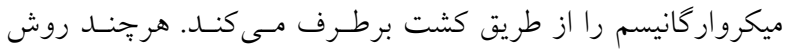
كشت بهعنوان استاندارد طلايى در تشخيص در نظر كر فته مى شــوده،

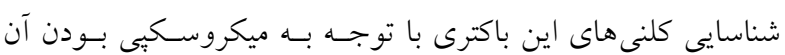
دشوار مى باشد و ممكن است نتايج مثبت يا منفى كاذب را با به همراه داشته باشد و نياز به افراد متخصص و تجربه دارد. بنـابراين در ايسن

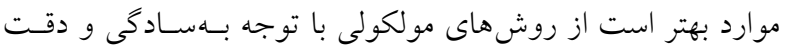

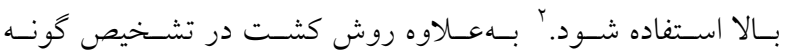

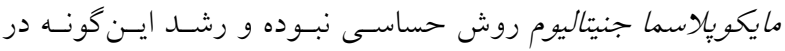

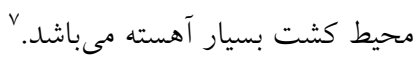

\section{نتيجه گيرى}

مطالعه حاضر نشان داد ميزان آلودگى مايكويلاسما در افر اد غيـر

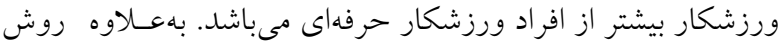

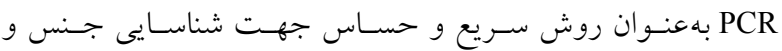
كو نههاى مايكويلاسما مى باشد.

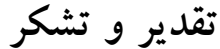

نويسندكان مقاله بر خود لازم مى دانند كه از مديريت و كاركنان آزمايشكاه تحقيقاتى ميكروبيولوزى بِاسار كاد تقدير و تشكر نمايند.
نمونه 9 نمونه از مردان و ه نمونه از زنان بوده است. Cunningham

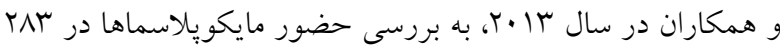

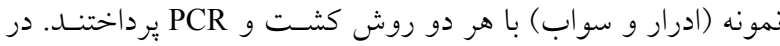

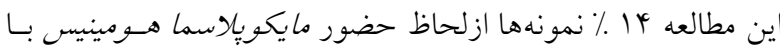
هـر دو روش مثبـت بودنــــ مر مطالعهـ Naher و Said در سـال

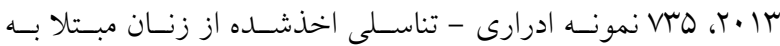
عفونتهاى ادرارى - تناسلى را از جهت حضـور مايكويلاسـماهاى

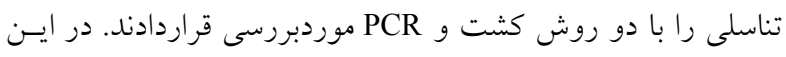

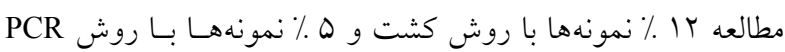

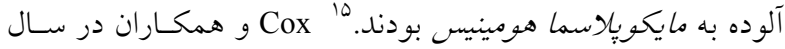

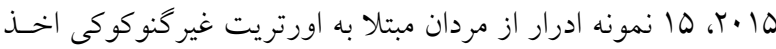

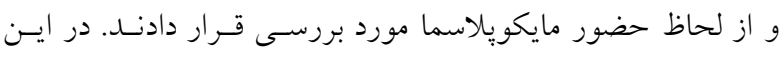

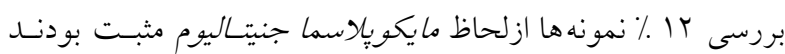

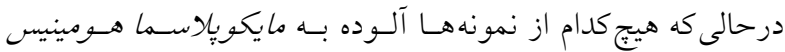

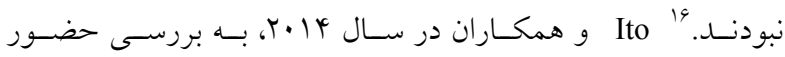

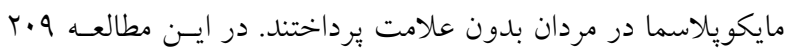

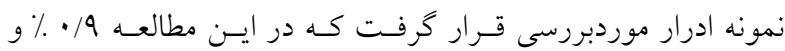

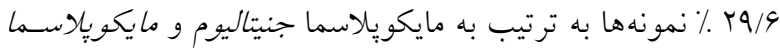

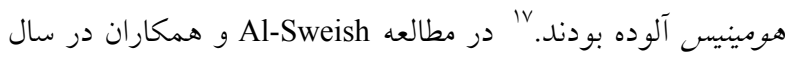

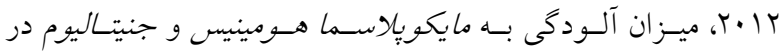
نمونههاى تناسلى مردان بارور و نابارور بررسى شد. در اين مطالعه ميزان آلودخى به مايكويلاسما هومينيس در مردان نابارور و بارور به به بانه

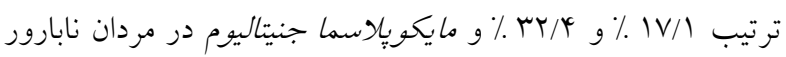

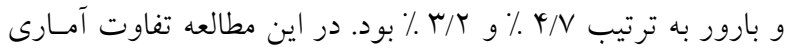
معنى دارى بين نمونههاى مردان بارور و نابارور مشاهده نشد هر ترجند وجود مايكو يلاسماهاى تناسلى اثر منفى روى كيفيـت اسـيرم نشـان

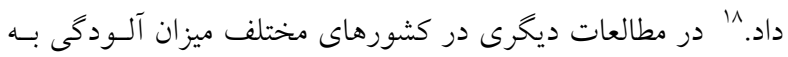
ما يكويلاسما جنيتاليوم در نمونهاى ادرارى-تناسلى مردان نابارور و سالم بررسى و نتايج مقايسه شد. Plecko و همكاران در سال 19 1.

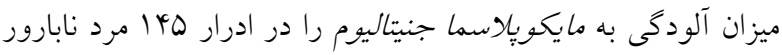

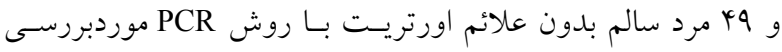

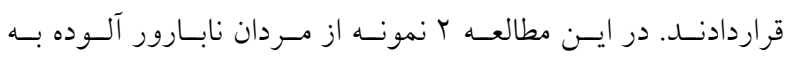
ما يكويلاسما جنيتاليوم بودند ولى در مردان سـالم آلـودكى بـهـ ايسن

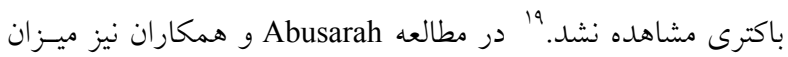




\section{References}

1. Moosavian SM, Motamedi H, Maleki S, Shahbazian N. Comparison between prevalence of Mycoplasma hominis and Ureaplasma urealyticum in women with urogenital infections by Multiplex PCR and culture methods. Med J Tabriz Uni Med Sci Health Services. 2011; 33(3): 91-97. [Full text in Persian]

2. Cunningham sA. Mandrekar JN, Rosenblatt JE, Patel R. Rapid PCR detection of Mycoplasma hominis,Ureaplasma urealyticum, and Ureaplasma parvum. Int J Bacteriol 2013; 1: 1-7.

3. Vosooghi S, kheirkhah B, kariminik A, mirshekari T R. A review of the role of Mycoplasma infections in humans' infertility . NCMBJ. 2012; 2 (8) :9-20. [Full Text in Persian]

4. Campos GB, Lobão TN, Selis NN, Amorim AT, Martins HB, Barbosa MS, et al. Prevalence of Mycoplasma genitalium and Mycoplasma hominis in urogenital tract of Brazilian women. BMC Infect Dis 2015; 15: 60-67.

5. Fanaei H, Mardaneh J, Khayat S. An overview of the role of bacterial infection in male infertility. J Fasa Uni Medi Sci 2012; 2(4): 227-234. [Full Text in Persian]

6. Friman G, Wesslen L. Infections and exercise in highperformance athletes. Immunol Cell Biol. 2000; 78: 51052.

7. Waites KB, Xiao L, Paralanov V, Viscardi RM, Glass JI.Molecular Methods for the Detection of Mycoplasma and Ureaplasma Infections in Humans. J Molecular Diagnos 2012; 14( 5): 437-451.

8. Moosavian SM, Pordeli HR. Survey of respiratory and urogenital infections due to Mycoplasma in the hospitalized patients in Ahwaz Imam Khomeini Hospital. Med J Kerman Med Sci Uni. 2004;4(10):185-192. [Full Text in Persian]

9. Vatani S, Ghazisaidi K, Mohamadi M, Naji AR, Fateminasab F, Zeraati $\mathrm{H}$, et al. The survey of contmination with genital Mycoplasma in women with bactrial vaginalis by PCR method. J Gorgan Uni Med Sci. 2006; 8 (1) :45-50. [Full Text in Persian]

10. Ghazisaidi K, Vatani S, Fateminasab F, Dehghanzadeh N, Mohamadi M. Evaluation of first voided urine samples for detection of Ureaplasma urealyticum and Mycoplasma hominis in urinary tracts of men and women suffering from nongonococcal and non specific urethritis. JSSU 2007; 15(2): 64-70. [Full Text in Persian]

11. Sadrpour P,Bahador A, Asgari S, Bagheri R,ChamaniTabriz. Detection of Chlamydia trachomatis and Mycoplasma genitalium in semen samples of infertile men using multiplex PCR. Tehran Uni Mel J 2013; 70(10): 623-629. [Full Text in Persian]

12. Najar Peerayeh Sh, Samimi R. Detection of Mycoplasma hominis in endocervix specimens from infertile women by PCR. Daneshvar Med 2007; 14 (66): 63-68. [Full Text in Persian]

13. Ahmadi MH, Amirmozafari N, Sedighi-Gilani MA, Kazemi B, Masjedian-Jazi F.Comparison of Culture with PCR for Detection of Mycoplasma hominis and Ureaplasma urealyticum in Semen Samples of Infertile Men Referring to the Royan Institute in 2009. Iran Uni Med Sci J 2009; 17(76): 16-29. [Full Text in Persian]

14. Ikonomidis A, Venetis C, Georgantzis D, Giaslakiotis V, Kolovos V, Efstathiou K, et al. Prevalence of Chlamydia trachomatis, Ureaplasma spp., Mycoplasma genitalium and Mycoplasma hominis among outpatients in central Greece: absence of tetracycline resistance gene tet(M) over a 4-year period study. New Microbe New Infect 2016; 9: 8-10

15. Naher HS and Said IH. Culturing and PCR methods for detection of Mycoplasma hominis and Ureaplasma urealyticum in women with genitourinary tract infections. Int Res J Medical Sci 2013; 1(3): 25-29.

16. Cox C, McKenna JP,Watt AP, Coyle PV. Ureaplasma parvum and Mycoplasma genitalium are found to be significantly associated with microscopy-confirmed urethritis in a routine genitourinary medicine setting. Int J STD Aids 2015; 26(1): 16-20.

17. Ito S, Kikuchi M, Seike S, Tsuchiya T, Yasuda M, Yokoi $\mathrm{S}$, et al. Prevalence of genital mycoplasmas in asymptomatic male partners of women diagnosed as having chlamydial infections. J Infect Chemother 2014; 20(2): 143-145.

18. Al-Sweish NA, Al-Fadli AH, Omu AE, Rotimi VO. Prevalence of Chlamydia trachomatis, Mycoplasma hominis, Mycoplasma genitalium, and Ureaplasma urealyticum infections and seminal quality in infertile and fertile men in Kuwait. J Androl 2012; 33(6): 1323-29.

19. Plecko V, Zele-Starcevic L, Tripkovic V, Skerlev M, Ljubojevic S, Plesko S, et al. Unusually low prevalence of Mycoplasma genitalium in urine samples from infertile men and healthy controls: a prevalence study. BMJ Open 2014; 4: 5372-76.

20. Abusarah EA, Awwad Z, Charvalos E, Shehabi AA. Molecular detection of potential sexually transmitted pathogens in semen and urine specimens of infertile and fertile males. Diagnostic Microbiol Infect Dis 2013; 77(4): $283-286$.

21. Ferandon C, Peuchant O, Janis C, Benard A, Renaudin $\mathrm{H}$, Pereyre S, et al. Development of a real-time PCR targeting the yidC gene for the detection of Mycoplasma hominis and comparison with quantitative culture. Clin Microbiol Infect 2011; 17(2): 155-59. 